\title{
Return of the Periphery? Globalisation, Climate Change and the Options for Forest Rich Regions
}

\author{
Cali Nuur, Michael Novotny, and Staffan Laestadius
}

\begin{abstract}
The aim of this paper is to analyse the conditions for a second wave of industrial dynamics of forestry rich regions in old industrialised nations which in the past contributed to the industrial competitiveness but today find themselves in the periphery of industrial development. The main argument is that the process of globalisation and climate change mitigations combined create a scramble for biomass and that this provide a golden opportunity for a revival of the industrial base of forest rich regions.

In the 21th century bioenergy applications and new biomaterials based on the properties of boreal trees are emerging in Scandinavia. These resources in combination with new technology can contribute with advanced materials and solutions in a world moving away from fossils. This emerging paradigm has some of the infrastructure already at place - i.e. pulp mills that for decades have been used for papermaking. At least to 2020, the scramble for bioenergy solutions might be a second best alternative in the climate change mitigation in order to reach the European policy goals. Considering our findings this might restrict the potential for biomass pathways with higher potential both from carbon sequestration and industrial development perspectives.
\end{abstract}

Index Terms-Climate change; peripheral regions; old industrialised resource rich nations; industrial dynamics.

\section{INTRODUCTION}

A century ago the county of Gävleborg located in Central Sweden, was at the epicentre of the industrialisation process that engulfed Sweden since the second half of the $19^{\text {th }}$ century Initially the regional economic landscape was characterized by small scale sawmills that mainly served local needs. During the $20^{\text {th }}$ century, this forest industry transformed towards pulp and paper manufacturing which dramatically increased in scale after World War two. By the middle of the $20^{\text {th }}$ century, a leading forest industry cluster that employed one of every six in the industry had evolved [1].

After 1970 this dynamic forestry cluster began to disintegrate as well as lose its character as local creator of employment and attractor of new industrial ventures. The mechanisms behind this structural change were many: the transformation from sawmills to large pulp and paper mills a heavy process industry - in itself reduced demand for labour; productivity increases contributed to upgrading of plants, closure of small production units and reduction of employees

Manuscript received March 23, 2012; revised May 3, 2012.

Authors are with the Department of Industrial Economics \& Mgmt, Royal Institute of Technology, KTH, Lindstedtsvägen 30, 10044 Stockholm, Sweden (e-mail: cali.nuur@ indek.kth.se; michael.novotny@indek.kth.se; staffan.laestadius@indek.kth.se). (from 240900 workers in 1970 to 95700 workers in 2010 on national level in the pulp and paper industry), communication technologies made it cheaper to concentrate production and export semi-finished products to distant markets [1]-[3]. This decline in employment had far reaching repercussions because of the then prevailing Swedish industrial model of single company towns in the rural areas making them vulnerable to outsourcing or closure of smaller/inefficient production units in favour of new and large ones [1]. In the case of Gävleborg for instance, all but four of the dozens of paper and pulp mills in the region - as well as most of the saw mills - have shut down during the past decades. Today, the occasional visitor to this region may witness a rustbelt which offers a testimony of the once enormous cluster not only providing employment opportunities but also contributing to Swedish industrial competitiveness [1].

The growth of the global economy during recent decades has resulted in a myriad of challenges for natural resource rich regions in old industrialised nations. Although their natural resource bases have historically contributed to regional competitiveness, they since long find themselves in a policy as well as academic discourse that has embraced nebulous concepts such as the "Knowledge Economy" [4]-[7], the "Information and Network societies" [8],[9], the "Creative Class" [10]-[13], "innovation systems" [14]-[16] and the "Resource Curse" [17]-[19] which have become part of the regional development discourse during recent years. Natural resources - and the regions where they can be harvested and extracted - seem to be something of the past!

There is, however, another side of the coin. The process of globalisation and the related rise of the emerging economies as well as the efforts to mitigate climate change together contribute to a growing transformation pressure on natural resources. It may be argued that we are witnessing a growing demand - an emerging scramble - for biobased resources of all kinds. Could this scramble revive the industrial dynamism of forest rich peripheral regions in old industrialized nations? Analyzing the conditions for a return of the forest rich periphery - a second wave of industrial dynamism - is the aim of this paper.

Our focus is on the resource rich regions such as the one described above which have stagnated into backwardness in the "post-industrial" transformation that took place after the peak in the 1960s. Based on our analysis of a forest rich peripheral region in Sweden we argue that the scramble for renewable resources under certain circumstances could present a golden opportunity to create new biomass pathways as well as contribute to climate change mitigation.

Apart from this introduction this paper consists of three 
other sections. In the subsequent section we discuss the scramble for biomass conditioned by globalisation and climate change. In section three, we analyse potential pathways for industrial dynamism in a forest rich peripheral region in Sweden. Finally, in section four we conclude the paper and discuss the implications.

\section{TOWARDS A NEW DYNAMICS OF BIOMASS BASED INDUSTRIES}

Forests cover over a third of the global land area [20], [21] Old industrialised nations in the northern hemisphere have large reserves of forests. For instance, Canada accounts for $10 \%$ of the earth's forests and $45 \%$ of its land area are covered by forests. In Finland, nearly $20 \%$ of value added in industry could be deduced to forest based activities. In Sweden the picture is basically the same; forest related activities still continue to play a key role in Swedish industrial competitiveness. Firms along the forest based value chain play a central role in Swedish industrial and technological competitiveness. Sweden has a revealed comparative advantage in forest based products on more than five times the OECD average [22]. Unlike many countries in the world, this natural resource - due to strong policy institutions - is not depleted; in fact, the Swedish growing forest stock - of which a majority consists of Scots pine, Norway spruce and birch - has increased by over $60 \%$ between 1930 and 2010. Forest land now covers 55\% of the country's land area [3].

While forest related activities (e.g. logging, wood, pulp and paper industries) still constitute the backbone of the industrial competitiveness in the northern hemisphere successive technological development has - as mentioned in the introduction - led to increase in labour productivity and a sharp reduction in employment in the traditional process industry. Parallel to that there has been increased spending on machine equipment, input material and technical consultancy firms contributing to more complex clusters or networks of firms in different phases of the value chain. In Sweden, exports of forest industry products increased (on national level) from 8 BSEK in 1970 to 128 BSEK ( 15 BEUR) in 2010 parallel to a decline of employment in the same period by more than $60 \%$ [2], [3].

Although natural resource based industries (NRBI:s) continue to play a pivotal role in the industrial competitiveness of old industrialised nations, peripheral natural resource rich regions have in recent decades witnessed a political as well as academic discourse that has declared natural resource basis as obsolete. The growth of the so called Tiger economies which has taken place without significant natural resource endowment has resulted in a discourse that asserts there exists a curse in natural resource rich countries and nations. What this discourse failed to consider is the fact that the industrial competitiveness of some of the richest countries in the world is shaped by the presence of a strong natural resource base. Which countries to include in this group may be subject to lengthy academic and policy discussions but we can discern countries such as Sweden, Finland [22]-[24], Canada, and Australia. For instance, Finland has $20 \%$ of its industrial production in forest industry products which accounts for $25 \%$ of export earnings (in Sweden 12\% GDP respectively 12\% of exports in 2010). In Australia, mining alone stands for more than $10 \%$ of GDP 2009-2010) and in Canada forestry and mining accounts for $14 \%$ of GDP in 2010.

The co-evolution of institutions and natural resource based industries has contributed to conditions favourable not only for competitive resource extraction but also to capability and competence migration along the value chain as well as to other industrial sectors. The polarized industrial structures of Finland and Sweden - the presence of high tech industrial sectors in parallel with natural resource based industries may illustrate this trend [22].

As the emerging economies develop from a marginal position i.e. producing industrial goods cheaper for markets in developed countries to becoming a significant player of the world resource transformation the situation changes: the pressure on natural resources becomes highly visible as more actors want to share them. Evidently, this development is a double edged sword for the emerging economies and for the other countries in the world; on the one hand as they leap forward and embark on a transition from poverty their domestic appetite for natural resources based commodities such as hydrocarbons, agricultural lands, wood, utensils, and fuels will outpace supply resulting in a scramble for renewable resources. On the other hand, the rise of these countries increases their share of environmental pollution threatening the thermal balance of the atmospheric system. The Chinese catching up is an illustrative example as it has resulted in a doubling of its share of $\mathrm{CO}_{2}$ emissions since the Kyoto protocol in 1997 and China will soon surpass industrialized nations in per capita terms [25]. In fact Chinese per capita emissions are already on the same level as those of Sweden (which today has the lowest emissions among old industrial countries).

The role of emerging economies may, on the one hand, be looked upon - somewhat simplified - as adding new demand for natural resources to the old. The implications of climate change may, on the other hand, be looked upon as - on top of the dramatically growing aggregate demand - causing structural transformation of this demand for natural resources. In short: for the transition to a sustainable low carbon economy to be efficient the use of highly GHG emitting resources must rapidly be substituted by "green” demand.

Large parts of this subsequent demand will be directed towards biomass, which, if managed properly with various forms of plantations ${ }^{1}$, may be looked upon as sustainable. It may be argued that the potential and sustainable harvests of all kinds of biomass may not be enough to satisfy all potential demand if we also plan to use it for fuels and other forms of energy. As our demand for fuels - at least in the short run - is high due to the perceived lack of alternatives it is easy to foresee that the recent price increases on biomass will continue for the coming decades. In summary all forms of biomass will become attractive for new markets, new products and new processes and as relative prices change they will substitute for each other.

Clearly spruce trees are bad substitutes for wheat and areas suitable for Scandinavian pine cannot easily be

\footnotetext{
${ }^{1}$ Asian countries are nowadays leasing fertile lands south of the equator; China, South Korea and Bangladesh have signed agreements with the governments of Zambia, Uganda and Tanzania. This underscores the onset of a new economic dynamism.
} 
transformed to grow sugar cane. But as most soils are suitable for many different species - and many species can substitute for each other in their end use - on a global level there is a potential for substitution between different species and types of biomass. In this paper the focus is on Scandinavian forests and biomass which can be grown in these areas still characterized by cold and snowy winters.

One obvious use of biomass - and not the least for wood is for energy. With the acceptance that climate change mitigation is a necessity, this energy source - viewed conventionally as low status fuel sources associated with poverty in the past - has prefigured as a key source of energy as the hunt for alternative sources intensifies. Although wood has been a recurring source of energy since the inception of human civilisation its importance has declined; it is estimated that only 20 percent of the present global energy supply is based on biomass. Only a fraction of this (less than 2\%) is used in old industrialised nations. The Nordic countries of Sweden and Finland stand out with $18-20 \%$ biomass rate respectively. However in these countries most of woody biomass to fuels is based on residues such as bark, stumps, twigs and branches, leftovers from wood processing industries while primary round wood is used for sawn and high value products. This rationalization of wood usage is totally different from what is the case in developing countries where more than $45 \%$ of primary wood is used as fuel wood [26].

Biomass is a renewable resource which can be purpose grown and includes by-products, woody or herbaceous, sugar crops or dung that could be treated organically processed into solid, liquid or gaseous biofuels and biochemicals that are manufactured from thermo-chemical and biological processing of wood. From the perspective of forestry, the amount of biomass derived depends on several factors such as forest management intensity (including fertilisation), recovery of forest biomass residues (including thinning residues, harvest slash, bark, branches and stumps), the use of fallow land for biomass cultivation, the selection of species to be cultivated, the level of wood products manufactured and the recovery of associated by-products and the recovery of post-consumer wood, paper, paperboard packaging waste [27].

Our main argument - of core importance for the conclusions of this paper - is that the emerging struggle for biomass and the price increases following from that will discriminate between different forms of biomass. Those species which have properties making them useful for more than eating, drinking and driving may face new end-uses in the economy. In particular coniferous trees such as spruce and pine and with high carbon sink capacity have the potential to show a high end-value. They have comparative advantages in their use for carbon fibre [28] or new wood building constructions such as wooden houses, bridges, etc., with high strength and high fire as well as earth quake resistance which can substitute for steel and cement constructions. Fast-growing fuel wood like poplar may be ideal for green chemicals and biofuels production in the Northern hemisphere. In part that is also the case for birch which has high heating value and - more important - a unique content, xylan - a precious platform biochemical - of almost $30 \%$ of total birch weight content, and of betulin (birch bark), an ideal feedstock for high value bioproducts (bioplastics, cosmetics, functional food, etc) [29].

This new use for forest resources will take place in transformed industries. This transformation may once again get the classical Schumpeterian character of creative destruction: the incumbent firms that still focus on pulp and paper will struggle against not only shrinking demand for printing papers and external players with different end-uses such as energy and petro-chemical industries - competing for the same biomass feedstock, but also higher prices on their raw material.

What we argue is that the tajga forests - found in North America, Europe and northern Asia - to a large extent consist of wooden species containing fibres that - in a context of growing shortage of biomass - can find more valuable end uses than just as fuels or even paper. Not the least do they have a potential future in construction of long lasting bridges, houses and artefacts which can serve also as carbon sinks. To a large extent this new end use of forest products can be done in medium sized production units which could contribute to employment and growth in remote areas now shipping their wood to distant highly automated and large saw mills and pulp plants. However, these production units are not found in today's wood processing sector and large saw mills. Basically, new entrants are needed to escape the lock-in.

Moreover, Swedish and other boreal forests in the Northern hemisphere have a large impact as a carbon sequestration source (approximately 30\% of global carbon sequestration comes from boreal forests - 2 Gt (Gigaton) carbon, the rest comes from oceans and the atmosphere accumulation). Not only the forest industry is the only large scale industry with a renewable feedstock, this industry is also the only large scale industry where the carbon sequestration is significantly higher than its actual $\mathrm{CO}_{2}$ emissions [26].

\section{POTENTIAL PATHWAYS OF REVIVED INDUSTRIAL DYNAMISM - THE CASE OF GÄVLEBORG IN SWEDEN}

It could be asserted that this second wave of forest based industrial dynamism is already emerging in terms of spattered hot spots in the old industrialised forest rich countries. In particular this second wave will be spurred where existing, mature forest industries experience a threat of losing cost competitiveness due to cheaper fibres in South America or of a future shrinking market for some traditional products (e.g. printing and writing papers). Also growing environmental concerns (not least the challenges of climate change) are putting high focus on the boreal forests that stand for more than $50 \%$ of global forest areas of which large part is located in old industrialised nations and more than $25 \%$ in Europe, which therefore play a great role in climate change mitigation.

Forest resources not only work as carbon sink and source for bioenergy, they contribute to other values such as high value fibres, recreation and biodiversity. In an outlook for the European Forest Sector made recently by UNECE/FAO - the EFSOS report - three hypothetical biomass pathways between 2010 and 2030 were analyzed from these perspectives: a) carbon sequestration b) biodiversity c) bioenergy. 
The first scenario explains how forestry should transform in order to maximize carbon sequestration without limiting the supply of wood and without using larger land areas than today. Necessary changes have to be made with regards to increasing the generation time of wood plantations (in Sweden ten years longer) and more thinning activities (+45\%) of trees instead of final harvesting. This would increase the carbon sequestration with $11 \%(+3000$ TgC -Teragrams of carbon) without reducing wood supply from the forests. But in order to accomplish this biomass pathway forest owners should have incentives to do significantly more thinning than harvesting activities (i.e. more labour intensive) [30].

The second scenario of biodiversity would increase forest land demand with 5\%. Final tree harvesting would be finalized later in order to increase older trees and for replantation of more leaf species in greater extent. This pathway, which does not include extraction of tops, branches and stumps have a positive impact on recreation, the eco-system (for example water quality) and have the largest increased carbon sequestration, +3400 TgC. However, it would create a large excess demand on wood supply (176 million cubic meters less of wood supply).

The third scenario analyses what it takes in terms of bioenergy to reach the goals of renewable energy in the EU. It is based on the goals for year 2020 (20\% renewable energy of total energy consumption, $10 \%$ biofuels, etc) a pathway that calculates a huge increase of biomass extraction in the EU (from 350 million to 750 million cubic meters) and a 300\% increase of biomass imports. Most of these biomass resources are expected to be extracted in Scandinavia and Russia and used for bioenergy applications such as heating, power and motor biofuels. This pathway would only increase carbon sequestration with $1750 \mathrm{TgC}$, approximately half of the other two pathways.

It may be argued that what pathway that will be followed by forest based industries depends on how future prices develop on biomass, competing and substituting products. If fossil fuel prices increase sharply, e.g. due to oil shortage or $\mathrm{CO}_{2}$ taxation, there will - in the absence of compensating policies - be strong demand for burning also high class tajga fibres. In addition, and not discussed in the EFSOS report, new, potentially radical innovations from the main wood compounds (cellulose and lignin) developed at pilot scale at Swedish and Finnish research institutes (carbon fibre from lignin and four-five times stronger nanofibers for paperboard packaging from cellulose) may compete for the biomass supply. Moreover, important technology shifts are since recently developed at several pulp mills located in the periphery that have or are about to transform into biorefineries - i.e. integrated lignocellulosic plants producing biomaterials and biocomposites from wood compounds, and bioenergy and biofuels from the wood or black liquor residues on site. The pulp mills of Södra Cell and Domsjö Fabriker located in Southern and Northern Sweden provide good examples [30].

Historically, Swedish forest industry has been rather successful in "moving forward in the value chain" [31]. From lumber/timber exports and charcoal in the $17^{\text {th }}-18^{\text {th }}$ century, and sawmill products in the $19^{\text {th }}$ century, pulp and paper industries in the $20^{\text {th }}$ century to biorefineries (biofuels, heat \& power, biochemicals, textiles etc) and a myriad of new biomaterials in the $21^{\text {th }}$ century successfully invented at research institutes located in Sweden and Finland such as Innventia and VTT (for example nanocellulose and lignin applications, to a large extent super strong materials to substitute metals/plastic packaging materials, etc). Basically, these are new products that potentially can substitute fossil based and mineral products with significantly higher $\mathrm{CO}_{2}$ emission levels (fuels, cement, metals, plastics, etc) [28]. This biomaterial and biochemical revolution based on the main compounds of wood have some of the infrastructure and technological capabilities already at place - i.e. chemical pulp mills that for decades have been used for papermaking. New entrants from other sectors (for example pharmaceutical and chemical industries) seem to be crucial in this new direction.

Going back to the case of Gävleborg there are examples of advanced industries moving away from the commodity trap. There is the advanced production plant of Arizona Chemicals outside the town of Söderhamn (15,000 inhabitants), an interesting case of high value added biomass pathway. It is a niche provider of high value products based on byproducts from the pulp mill. Arizona Chemicals is far from the commodity style that characterizes many pulp and paper producers. It refines pine oil, an organic chemical and a residue from pulp mill operations that is processed at the site into fatty acids, distilled pine oils, pine oil rosins, sulfate turpentine derived products to the global coatings, inks, resins, fuel additives and lubricants industries, products with price levels per kg of those of paper pulp per ton, etc.

A second example is Svenska Aerogel, a research and development company based in Gävle, the capital of Gävleborg county (90 000 inhabitants), that recently commercialized a patented version of aerogel, a material with applications such as insulation of wood constructions which makes them fire resistant up to $650^{\circ} \mathrm{C}$ which in turn may transform them to potential partners of wood processing industry and sawmills in the region.

A third is the paperboard producer of Iggesund. The company has developed a paperboard for the most sophisticated markets- cellulose fibre packaging material for luxury products (perfumes, beauty, and present articles). The flagship of the production plant, the Invercote paperboard, has been chosen as the strongest brand on the exclusive European consumer paperboard market during a long period of time. This conclusion comes from European brand surveys based on over 700 interviews with paperboard converters and brand owners [32]-[34]. The paper mill is integrated with a sawmill which produces sawn products out of spruce and pine roundwood for the construction sector. The wood chips residues from the sawmill are used in the pulp and paper units. The production site is self-sufficient on electricity and its energy needs is to 95\% generated by biomass residues (bark, saw dust, bio sludge, black liquor, etc) from the internal production process ${ }^{2}$.

\footnotetext{
${ }^{2}$ The high value added of Arizona Chemical in Söderhamn is expressed by the turnover of 200 MEUR (more than 1 million EUR per employee). Iggesund Paperboard (including saw mill operations) has roughly 1000 employees and a turnover of 650 MEUR per year.
} 


\section{CONCLUSION}

Undoubtedly, the recent growth of the global economy has resulted in a myriad of challenges for natural resource rich regions in old industrialised nations. The process of globalisation and the ensuring rise of the emerging economies, climate change and the mechanisms to mitigate have combined to necessitate transformation pressures on natural resource based economic activities. This development shed new lights also on the old problem of resource scarcity manifested recently by terms such as "oil peak", “cotton peak" and "phosphorous peak". The implications of climate change may, on the other hand be looked upon as causing structural transformation as regards the demand for natural resources: from highly Greenhouse Gas (GHG) emitting resources to lowly - or non - emitting resources. In order to make the transition to sustainability an efficient one the use of highly GHG emitting resources should rapidly be reduced in favour of investments in renewable biomass feedstocks, biorefining processes and new biomaterials.

Whether the biomass resource rich periphery of the centre, like Gävleborg, can grasp the opportunities of the new struggle for biomass and transform them into a new and second wave of industrial dynamics is still an open question. Business as usual from the periphery in the old industrialised countries will probably not be enough to propel this huge transformation towards radically new biomaterials and low carbon strategies in forestry. Growing environmental concerns (not the least climate change), emerging economies (BRIC's) and diminishing oil reserves, contribute to a scramble for biomass causing new conditions and potentially a renaissance for biomass industries. Wood streams are becoming hot like oil feedstocks were in the beginning of the twentieth century. New interest from all large scale industry sectors (in particular energy, chemical, pharmaceutical and advanced construction industries) towards the extracting of the two most abundant biomass compounds in the world, cellulose and lignin, have resulted in an emerging renaissance for biorefining processes and new biomaterials. Strong uncertainties of future relative prices (of fossil fuels as well as on greenhouse gas emissions) will also add to the challenges for the biomass based industries.

In the short run, at least to 2020, the scramble for woody bioenergy might turn out to be a second best alternative in the climate change mitigation in order to reach the European policy goals. This may restrict the potential for alternative biomass pathways with higher long term potential both from a carbon sequestration perspective and from industrial and technological perspectives. It will, consequently, even though the study showed a limited number of successful examples, be a heavy task for the incumbent forest industry saw mills and pulp and paper plants in primis - to upgrade into biorefining activities with higher value added thus exploiting the potential of the taiga fibre or the natural potential of the wood compounds. In short: it is far from obvious that the tajga fibre rich regions and the industries located there may - in the short term - grasp the high end opportunities created by this biomass revolution.

\section{REFERENCES}

[1] C. Nuur and S. Laestadius, "Development in peripheral regions; Case studes in Sweden”, European Urban and Regional Studies, vol 17, no 3, pp. 293-307, 2010.

[2] Skogsstatistisk årsbok, Skogsstyrelsen, 1971 (Forest Statistical Yearbook, 1971, Swedish Forest Agency, Jönköping, Sweden)

[3] Skogsstatistisk årsbok, Skogsstyrelsen, 2011 (Forest Statistical Yearbook, 2011, Swedish Forest Agency, Jönköping, Sweden)

[4] D. Archibugi, and Coco, A. "Is Europe Becoming the Most Dynamic Knowledge Economy in the World? “, JCMS: Journal of Common Market Studies, Vol 43, no 3, pp. 433-459, 2005.

[5] C. Nuur and S. Laestadius, "Stuck in the middle? A case study of the underutilised potential in peripheral regions in developed countries in the age of globalisation", Journal of Regional and Community Development, vol. 2 no.2 pp 44-63, 2007.

[6] P. Cooke, "Regional Innovation Systems, Clusters, and the Knowledge Economy”. Industrial and Corporate Change, Vol.10, no. 4 pp. 945-974, 2001.

[7] W. W. Powell, “The Knowledge Economy”. Annual review of Sociology, vol. 30, pp. 199-220, 2004.

[8] M. Castells, The Rise of the Network society. Wiley-Blackwell, 2000.

[9] C. Fuchs, Internet and Society: Social Theory in the Information Age. New York: Routledge. Routledge Research in Information Technology and Society Series Number 8, 2008.

[10] C. Nuur and S. Laestadius, "Is the creative class necessarily urban? Putting the creativity thesis in the context of non-urbanised regions in industrialised nations” European Journal of Spatial Development. Debate, pp 1-12. 2009.

[11] R. Florida, "The economic geography of Talent" Annals of the association of American Geography 92(4) 743-755. 2002

[12] R. Florida, The Rise of the Creative Class: And How It's Transforming Work, Leisure, Community and Everyday Life, Basic Books, New York, NY. 2002

[13] R. Florida, The Flight of the Creative Class: The New Global Competition for Talent, Harper Business, New York, NY. 2005

[14] C. Nuur, L. Gustavsson, S. Laestadius, "Promoting Regional Innovation systems in a Global context. Industry and Innovation, vol. 16 no. 1 pp 123-139, 2009.

[15] [15] R. Florida, Cities and the Creative Class, Routledge, New York, NY. 2004.

[16] C. Landry, The Creative City: A Toolkit for Urban Innovators, Earthscan Ltd, 2000.

[17] R. M. Auty, "Industrial policy reform in six large newly industrialising countries: The resource curse”. World Development, vol. 22, pp. 11-26. 1994.

[18] R. M. Auty, "Natural resources, the state and development strategy". Journal of International Development, vol.9, pp. 651-663, 1997.

[19] J. D. Sachs, and A. M. Warner, "Natural Resources and Economic Development. The curse of natural resources”, European Economic Review. vol.45, pp. 827-838, 2001.

[20] M. Parikka, "Global Biomass Fuel Resources". Biomass and Bioenergy, vol.27, pp. 613-620, 2004.

[21] B. Hillring, and M. Trossero, "International wood fuel trade - an overview”. Energy for Sustainable Development. Vol. X, no 1, pp. 33-41, 2006.

[22] C. Nuur, and S. Laestadius, "The Anomalies of the Resource Curse Paradigm: The Case of Sweden”, TRITA-IEO-R 2009:01.

[23] M. Blomström, and A. Kokko, "From Natural Resources to High-Tech Production: The Evolution of Industrial Competitiveness in Sweden and Finland", EIJS Working Paper Series 139, The European Institute of Japanese Studies, 2002.

[24] K. O'Rourke, and J.G. Williamson, "Open Economy Forces and Late 19th Century Scandinavian Catch-Up", Harvard Institute of Economic Research Working Papers 1709, Harvard - Institute of Economic Research. 1995.

[25] V. Bosetti, C. Carraro and M.Tavoni, "A Chinese commitment to commit: can it break the negotiation stall?” Climatic Change, Volume 97, Numbers 1-2, 297-303, 2009.

[26] UNECE/FAO, "Forest products - annual market review. Innovation for structural change recovery", Geneva Timber and Forest Study Paper 25, Geneva, 2009-2010.

[27] B. Kamm, P. Gruber, and M. Kamm, Biorefineries - Industrial Processes and Products. Wiley-VCH Verlag GmbH \& Co, 2010.

[28] I. Norberg, "Carbon fibers from kraft lignin”, doctoral dissertation, Innventia/Royal Institute of Technology - Department of Chemistry and Polymers, 2012.

[29] [29] P. Axegård, "Bioraffinaderiets möjligheter att skapa kemikalier och material" [The potential of new chemicals and material in 
biorefineries]. Presented at the Packaging materials of the future conference. Kista Entré, Stockholm, November 15, 2011.

[30] UNECE/FAO, European Forest Sector Outlook Study II, Geneva Timber and Forest Study, Geneva, 2011.

[31] M. Novotny, and S. Laestadius, "Beyond papermaking transformation of forest industries: implications for R\&D and radical innovation". Presented at the R\&D management conference in Norrköping, June, 29, 2011.

[32] B.N. Hylander, "The shift in technology drives in the global forest products industry”, presented at CAETS Conference, Calgary, July 2009.

[33] Nordisk Papperstidning, "Iggesund's brands considered most valuable brands in Europe”, no 7, 2008.

[34] RISI Wood biomass markets, "Invercote maintains top position in Opticom's cartonboard brand tracking survey”, press release, June 17, 2010.

[35] Opticom, "Brand specification process developing among converters and consumer goods brand owners - challenges for cartonboard producers”, Press release, September 12, 2006.

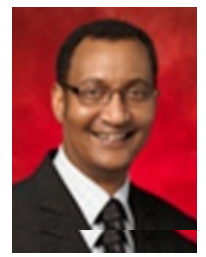

Cali Nuur is an associate professor, at Department of Industrial Economics \& Management (INDEK), Royal Institute of Technology (KTH), Stockholm.

His research Fields is Innovation systems; Economic and technological transformations; the dynamics of natural resource based industries; Development in the peripheries; Sustainable development.

Dr. Nuur received his PhD in 2005 on : "Cluster Dynamics and Industrial Policy in Peripheral Regions - A study of cluster formation as a local development process". PhD/Doctoral thesis in Industrial Economics and Management. Royal Institute of Technology.

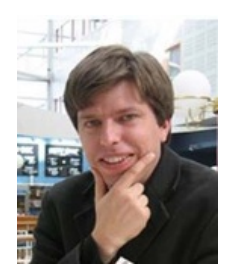

Michael Novotny is a $\mathrm{PhD}$ candidate at INDEK, Royal Institute of Technology, Stockholm. Research field: Transformation of pulp \& paper industries, Innovation Management in forest industries; Technological innovation systems. Current research: Innovation \& Industrial Transformation of wood based biorefineries, also a part of new economics of NRBI.

Former Editor-in-Chief of Nordisk Papper \& Massa, major Nordic Pulp \& Paper Magazine in Scandinavia (2005-08).

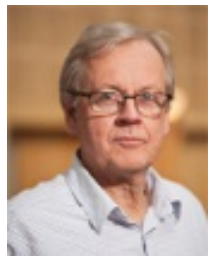

Staffan Laestadius is Professor of Industrial Dynamics at Department of Industrial Economics \& Management (INDEK), Royal Institute of Technology (KTH), Stockholm (Oct 2003 -),Vice Dean for PhD programmes at KTH/ITM-School (Jan 2007 - ). 